\title{
Rotation of the Maxillary Central Incisors in Nepalese Inhabitants
}

\author{
Masashi Sakuma*, Shuichi Nakamura**, Ichiro Semba***, \\ Kazunori Abe* ${ }^{*}$ Hideo Ohno** and Takao Ogawa"\# \\ *Department of Oral Anatomy (Chief: Associate Prof. Masashi Sakuma) \\ Junsei Junior College, Okayama, Japan \\ ${ }^{* *}$ Department of Phsyology (Chief : Prof. Satoshi Nakahara) \\ Kyushu Dental College, Kitakyushu, Japan \\ ***Department of Oral Pathology (Chief : Prof. Motoo Kitano) \\ Kagoshima University Dental School, Kagoshima, Japan \\ \# Department of Biochemical Nutrition (Chief: Prof. Kazunori Abe) \\ Seinan Jogakuin Junior College, Kitakyushu, Japan \\ \#\# Department of Operative Dentistry (Chief: Prof. Masamichi Terashita) \\ Kyushu Dental College, Kitakyushu, Japan
}

\begin{abstract}
Key words : Dental anthropology/Rotation/Maxillary central incisor/Abnormal alignment / Nepalese
\end{abstract}

Accepted on December 24, 1993.

\section{Introduction}

Mesiopalatal rotation (winged teeth : WT) of the maxillary central incisors is frequently encountered in some human populations, this is due to the rotated position of this teeth in sockets. The distal part of the crown is turned forward and the mesial part is in a lingual position. Enoki $(1958)^{1)}$ reported bilateral winging in $9.64 \%$ of 1,089 school children in Japan. On the other hand, the reverse position of mesiopalatal rotation, that is mesiolabial rotation (counter-winged teeth : CWT) also occurs in varying frequency, with a higher incidence among groups having narrow palates such as Caucasians. According to Dahlberg (1959) ${ }^{2)}$, $42 \%$ of the Caucasian group showed counter-winging, but only $3 \%$ showed the winging trait. This counter-winged position gives the impression of a pointed prominence of the maxillary incisor region. Both condition, WT and CWT, can be seen unilaterally and bilaterally. WT has been described by Rothhammer et al. (1968) ${ }^{3)}$ as a trait characterizing Mongoloid populations due to its relatively high frequency in those groups compared with Caucasian populations. The reasons for these racial difference are not known, but may sugest a genetic cause for WT.

The purposes of this paper are to study the frequencies of the mesiopalatal rotation of the maxillary central incisors among the Nepalese, and to examine its relation to spaciersion of maxillary incisors, the classification established by Dahlberg $(1959)^{2)}$ was adapted. As it was, 


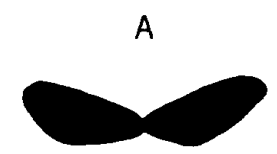

Bilateral winging

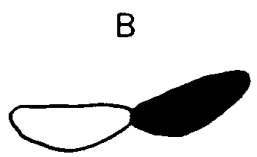

Unilateral winging



Straight

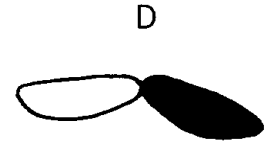

Unilateral counter-winging

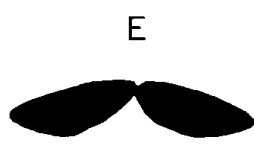

Bilateral counter-winging

Fig. 1 Classification of rotated central incisors by Dahlberg (1959) ${ }^{2)}$.

five types of Position were used in this study. These included all teeth in straightened alignment, bilateral winging, unilateral winging, bilateral counter-winging, and unilateral counter-winging (Fig. 1). The existence of central crowding was presumed when so-called "multiple crowding" was observed in upper anterior region, and of spacing when a diastema between maxillary central teeth was greater than $1 \mathrm{~mm}$. In addition, chi-square analysis were applied throughout in statistical comparisons.

\section{Results and Discussion}

The distribution of different types of roated maxillary central incisors is shown in Table 1 with the sex separated. The absence of sexual dimorphism of the trait was revealed by the lack of a statistically significant difference between its incidence in males and females $\left(\chi^{2}=\right.$ 1.088 with $\mathrm{df}=4,0.90>\mathrm{P}>0.85)$. We, therefore, decided to pool the data and the following descriptions were based on these data (Table 1 ). The highest frequency of rotational version of the maxilary central incisors was found in Type C (straightened teeth, 55.7\%). Of these $5.7 \%$ exhibited bilateral and $1.4 \%$ unilateral WT. On the other hand, for CWT, 32.9\% were bilateral and $4.3 \%$ unilateral. The frequencies of rotated maxillary central incisors in several populations are listed in Table 2. All these data were obtained according to the criteria for classification developed by Dahlberg $(1959)^{2}$. First of all, it is easily recognized that a higher frequency of bilateral CWT (32.9\%) is found in the Nepalese than in Mongoloid and Pacific populations, who ranged from $16.6 \%$ for the Palauan ${ }^{4)}$ to $0.0 \%$ for the Melanesian ${ }^{5}$. However, the frequency of CWT in the Nepalese is relatively close to the value for American White ${ }^{2)}$ and Pashtuns ${ }^{6)}$ derived from Caucasian racial stock. As opposed to this, the Nepalese frequency of bilateral WT (5.7\%) is lower than those observed in Mongoloid and Pacific racial groups. This value is quite similar to that of the Pashutun, of course, all the groups

Table 1 Distribution of rotated maxillary central incisors (individual count)

\begin{tabular}{lccccr}
\hline \hline Type & A & B & C & D & \multicolumn{1}{c}{ E } \\
\hline Male & $2(4.3)$ & $1(2.1)$ & $26(55.3)$ & $2(4.3)$ & $16(34.0)$ \\
Female & $2(8.7)$ & $0(0.0)$ & $13(56.5)$ & $1(4.3)$ & $7(30.4)$ \\
Total & $4(5.7)$ & $1(1.4)$ & $39(55.7)$ & $3(4.3)$ & $23(32.9)$ \\
\hline
\end{tabular}

Classification is adapted from Dahlberg $(1959)^{2)}$

Numbers in parentheses are percentages. 
Table 2 Percentage incidence of rotated maxillary central incisors in several populations

\begin{tabular}{|c|c|c|c|c|c|c|}
\hline Sample & A & $\mathrm{B}$ & $\mathrm{C}$ & $\mathrm{D}$ & $E$ & Source \\
\hline Nepalese & 5.7 & 1.4 & 55.7 & 4.3 & 32.9 & Present study \\
\hline American White & 3 & 3 & 46 & 8 & 42 & Dahlberg $(1959)^{2)}$ \\
\hline Pashtun & 5.6 & 2.8 & 33.3 & 11.1 & 47.2 & Iizuka $(1979)^{6)}$ \\
\hline Japanese & 9.7 & 15.1 & 52.1 & 9.2 & 13.9 & Enoki \& Nakamura (1959) \\
\hline Palauan & 7.3 & 11.5 & 59.4 & 5.2 & 16.6 & Sakuma et al. (1987) ${ }^{4)}$ \\
\hline Melanesian & 19.6 & 4.3 & 76.1 & 0.0 & 0.0 & Turner \& Swindler $(1978)^{5)}$ \\
\hline Easter Islander & 11.0 & 0.9 & 83.9 & 0.0 & 4.2 & Turner \& Scott $(1977)^{7)}$ \\
\hline
\end{tabular}

Classification is adapted from Dahlberg (1959) ${ }^{2)}$

Table 3 Percentage incidence of the piastema between maxillary central incisors

\begin{tabular}{lrcl}
\hline \hline Sample & $\mathrm{N}$ & $\%$ & \multicolumn{1}{c}{ Source } \\
\hline Nepalese & 70 & 4.29 & Present study \\
Japanese & 105 & 3.36 & Susami et al. (1971) ${ }^{8)}$ \\
Caucasian & 1337 & 5.61 & Mills $(1966)^{9)}$ \\
Chewa & 166 & 20.4 & Sakuma $(1989)^{10)}$ \\
\hline
\end{tabular}

Diastema greater than $\mathrm{lmm}$ between maxillary central incisors.

Table 4 Percentage incidence of the crowding and spacing at maxillary anterior segment

\begin{tabular}{lccl}
\hline \hline Sample & Crowding $^{*}$ & Spacing $^{* *}$ & \multicolumn{1}{c}{ Source } \\
\hline Nepalese & 5.71 & 7.14 & Present study \\
Japanese & 9.97 & 5.03 & Susami et al. (1971) ${ }^{8)}$ \\
Chewa & 5.42 & 28.31 & Sakuma $(1980)^{10)}$ \\
\hline
\end{tabular}

* : Multiple crowding

** : Excluded from the midline diastemas

have a large number whose central incisors are aligned straight in the normal arch curves. These range from $33.3 \%$ in the Pashtun to $83.9 \%$ in the Easter Islander ${ }^{7} .55 .7 \%$ of Nepalese samples exhibited this tooth position. The Nepalese showed an intermediate frequency between Caucasian and Pacific populations. Judging from the above-mentioned facts, it is concluded that the maxillary rotational version of the Nepalese is closely similar to Caucasian populations as a whole, but differ from Mongoloid and Pacific racial groups. With the diastema between maxillary central incisors (Table 3 ), the frequency of Nepalese (4.29\%) is more or less close to the values for Japanese ${ }^{8)}$ and for the Caucasian ${ }^{9)}$, and remarkably lower than the $20.4 \%$ for the Chewa ${ }^{10)}$ derived from African Negroid racial stock.

Finally, we focused on the relationships between the rotated central incisors and abnormal alignment such as crowding and spacing (Table 4). Crowding of the maxillary anterior region was found in 4 cases $(5.71 \%)$ out of 70 . This version of the crowding among Nepalese is almost similar to that of the Chewa. On the other hand, 5 cases (7.14\%) out of 70 showed the lateral spacing in maxillary anterior segment. The percentage incidence of 
Nepalese is obviously lower than that of the Chewa. Pearson's correlation coefficients between rotated central incisors and abnormal alignment at maxillary anterior segment were 0.2104 (crowding) and 0.1614 (spacing), respectively. These coefficients are quite low, and no significant relationships are found at the $5 \%$ level in the Nepalese. This evidence suggests that this particular trait is not caused by a surplus of space for the teeth (spacing) or a lack of space (crowding) but by other factors such as morphogenetic elements of the teeth root. To investigate this point in more detail, much additional studies must be acquired.

\section{Acknowledgments}

The authors are deeply indebted to the staff of the Nepal Anti Tuberculosis Association for their helpful assistance and cooperation. We also express sincere gratitude to Prof. T. Ogata, Kagoshima University Dental School, for his valuable suggestions. This study wag supported in part by Grant-in-Aid for Scientific Research on Priority Areas from Ministry of Education, Science and Culuture in Japan : "Prehistoric Mongoloid Dispersals", No.043.

\section{References}

1) Enoki, E. : Rotated maxillary central incisors among Japanese. J. Orthod. Jpn. $17: 161-169$, 1958. (In Japanese)

2) Dahlberg, A. A. : A wing-like appearance of upper incisors among American Indian. J. Dent. Res. $38: 203-204,1959$.

3) Rothhammer, F., Lasserre, E., Blanco, R., Covarrubias, E., and Dixon, M. : Microevolution in human Chilean population. IV. Shovel shape mesial-palatal version and other dental traits in Pewenche Indians. Z. Morph. Anthrop. $60: 162-169,1968$.

4) Sakuma, M., Mine, K., Roberts, T., Kumangai, M. and Polloi, A.: The rotation of the maxillary central incisors among inhabitants in the Republic of Palau. In : Prompt Rep. 5 th Sci. Surv. South Pacific, Kagoshima Univ. Res. Center South Pacific, Kagoshima, 1987, 71-75.

5) Turner II, G. R. and Swindler, D. R. : The dentition of New Britain West Nakanai Melanesians. Am. J. Phys. Anthrop. $49: 361-372,1978$.

6) Iizuka, A. : The bilateral mesiopalatal rotation of upper central incisors. Anthrop. Soc. Nippon 84 : $31-47,1976$. (In Japanese)

7) Turner II, G. R. and Scott, G. r. : Dentition of Easter Island. In : Orofacial growth and development. (ed. by Dahlberg, A. A. and Graber, T. M.). Mount Publishers, Hague. 1977, $229-249$.

8 ) Susami, R., Asai, Y., Hirose, K., Hosoi, T., Hayashi, I. and Kitamoto, T. : The Prevalence of malocclusion in Japanese school children. Part 1. Total frequency. J. Orthod. Jpn. 30:230-239, 1971. (In Japanese)

9) Mills, L. F. : Epidemiologic studies of occlusion. IV. The prevalence of malocclusion in a population of 1,455 school children. J. Dent. Res. $17: 332-336,1965$.

10) Sakuma, M. : Morphological variation in the African Negroid dentition. J. Anthrop. Soc. Nippon $97: 245,1989$. 


\section{ネパール住民における上顎中切歯の捻転について}

佐 熊 正 史* -中 村 修 - ***仙 波 伊知郎 ${ }^{* * *}$

安部 一 紀 ・大 野 秀 夫** ${ }^{* *}$ 小川孝 雄\#

*順正短期大学口腔解剖学講座（主任：佐熊正史助教授）

**九州㐘科大学生理学講座 (主任 : 中原 敏教授)

*** 鹿児島大学歯学部口腔病理学講座（主任：北野元生教授）

"西南女学院短期大学食物栄養科栄養生化学研究室 (主任: 安部一紀教授)

\#\#州歯科大学歯科保存学第 1 講座（主任：寺下正道教授）

下顎中切歯の近心舌側捻転 (winged teeth：WT) はモンゴロイド集団に特徵的に認められる形質と考えら れている. 一方，遠心舌側捻転 (counter-winged teeth：CT）はコーカソイド集団に比較的高い頻度で認 めら扟る．今回は上記のような上顎中切歯の特徴的な配 列について，ネパール国住民 70 名から得られた歯牙石 膏模型をもちいて検索した。 上顎中切歯が示す捻転状態 は Dahlberg（1959）の分類に基づいて判定し，以下の ような結果を得た。両側性遠心舌側捻転はモンゴロイド や太平洋集団に比べ，ネパール人では比較的高頻度に見 られ，コーカソイド集団にやや類似していた。一方，近 心舌側捻転の頻度はネパール人ではモンゴロイドや太平
洋集団より低かった。これらの結果からは，ネパール人 に㧍ける上顎中切歯揄転の様式はコーカソイド集団に比 較的類似しておりモンゴロイドや太平洋集団とはやや異 なると考えられた。ネパール人における上顎切歯部の歯 列異常については，叢生が 70 例中わずかに 4 例見られ たにすぎない，一方，側方および正中歯間離開は各々 $7.14 \%$ および $4.29 \%$ に認められた。

また，上顎中切歯における捻転之配列異常の頻度には 有意な相関は認められなかった。このことから，上領中 切歯の捻転様式は歯間の離開や狭窄によるものでなく， 歯根の形態など，他の要因によるものと考えられた。 